\title{
MODEL PEMBINAAN ANAK JALANAN DI PONDOK PESANTREN SALAFIYAH SABILUL HIKMAH MALANG
}

\author{
Anita Dwi Agustin, Rohmad Widodo, M.Syahri \\ FKIP Universitas Muhammadiyah Malang \\ Email : aanitadwi@gmail.com
}

\begin{abstract}
ABSTRAK
Tujuan penelitian ini adalah untuk mengetahui dan mendeskripsikan: 1) Model pembinaan anak jalanan di Pondok Pesantren, 2) Kendala-kendala yang terjadi dalam pembinaan anak jalanan, 3) Mengatasi kendala yang ada. Penelitian ini menggunakan pendekatan penelitian kualitatif dengan jenis penelitian deskriptif. Teknik pengumpulan data meliputi: observasi, wawancara, dan dokumentasi. Adapun metode analisis datanya melalui: pengumpulan data, reduksi data, penyajian data, dan penarikan kesimpulan. Hasil dari penelitian menjelaskan bahwa: 1) Pembinaan yang dilakukan di Pondok Pesantren Salafiyah Sabilul Hikmah ini adalah pendekatan secara personal sosial dimana pengurus pondok pesantren harus berinteraksi sosial secara anak per anak agar tahu apa yang sebenarnya diinginkan oleh masing-masing anak serta pembinaan dengan pendekatan secara agama (religius), 2) Kendala yang paling menonjol adalah sulitnya masa peralihan anak-anak yang semula hidup bebas dijalanan dan kemudian hidup di lingkungan pondok pesantren serta kurangnya dana operasional untuk mencukupi kebutuhan sehari-hari para santri, 3) Mengatasi anak yang susah diatur adalah dengan membuat anak - anak tersebeut merasa nyaman maka itulah guna dari pembinaan melalui pendekatan personal sosial, sedangkan kendala dari keuangan adalah bagaimana pendiri Pondok Pesantren menggunakan uang pribadi dalam mencukupi kebutuhan sehari-hari para santri.
\end{abstract}

Kata Kunci : Model Pembinaan, Anak Jalanan, Personal sosial dan religi.

\begin{abstract}
The research objective is to understand and describe: 1) The mentoring model for street children at Islamic Boarding School, 2) The problems in mentoring for street children, and 3) The solution for solving the problems. This research applied the descriptive qualitative research. The techniques for data collection were observation, interview, and documentation. The analysis data started from data collection, data reduction, result of research and conclusion. The result of this research showed that: 1) The mentoring which was done by Salafiyah Sabilul Hikmah Islamic Boarding School was a personal and social approach where Islamic boarding school staffs should make an social interaction to each of street children so they could understand their real needs, 2) the most problem which faced by street children was the difficulties on their adaptation from the life street to Islamic boarding school which did not have a good financial to support all their daily needs, and 3) To mentor the street childern who could not be taught easily was by making them feelmore comfortable so it aligned with the goal of a personal and social approach, and to cover the lack of financial on the student's daily needs was by using the staff's personal money.
\end{abstract}

Keywords: Mentoring Model, Street Children, Personal and social approach, and religion. 


\section{PENDAHULUAN}

Anak jalanan merupakan suatu permasalahan yang belum teratasi oleh bangsa Indonesia. Terutama di kota-kota besar, seperti Kota Malang. Anak jalanan tersebut, merupakan suatu pandangan yang kurang begitu bagus. Menurut UU No. 23 Tahun 2003 tentang Perlindungan Anak, anak adalah seseorang yang belum berusia 18 tahun, termasuk anak yang masih dalam kandungan. Dalam kehidupan berbangsa dan bernegara anak merupakan generasi penerus bangsa yang harus mendapatkan perlindungan dari pemerintah. Dalam Undang-Undang Dasar Negara Republik Indonesia Tahun 1945 pasal 34, ayat (1) yang berbunyi: Fakir miskin dan anakanak terlantar dipelihara oleh Negara.

Menurut pandangan Suyanto dalam Nugroho (2010: 5), “anak jalanan adalah anak-anak yang tersisih,marjinal, dan teralienasi dari perlakuan kasih sayang karena kebanyakan dalam usia yang relatif dini sudah harus berhadapan denganlingkungan kota yang keras dan bahkan sangat tidak bersahabat.

Dalam menegakkan hak anak, hal ini terus diperjuangkan oleh Perserikatan Bangsa-Bangsa (PBB) bagaimana tercantum dalam, Universal Declaration of Human Right, mulai dari hak hidup, hak kemerdekaan, hak kesejahteraan, hak pengasuhan, hak perlindungan, hak memperoleh pendidikan, hak menjalankan agama sesuai dengan keyakinannya, sebagaimana manusia memiliki martabat, nilai-nilai kebebasan, dan dalam lingkungan kebebasan yang lebih luas. (Marwan, 2015:14)

Dalam Konstitusi atau UndangUndang Dasar Negara Republik Indonesia (UUD) tahun 1945, pada pasal 28B ayat (2) yang menegaskan bahwa setiap anak berhak atas kelangsungan hidup, tumbuh, dan berkembang serta berhak atas perlindungan dari kekerasan dan diskriminasi (amandemen/perubahan kedua). Konsekuensi dari ketentuan pasal 28b Undang-Undang Dasar Negara Republik Indonesia Tahun 1945 perlu ditindak lanjuti dengan membuat kebijakan pemerintah yang bertujuan untuk melindungi anak. (Marwan, 2015:14)

Anak perlu mendapat perlindungan dari dampak negatif arus pembangunan yang cepat, arus globalisasi dibidang komunikasi dan informasi, kemajuan ilmu pengetahuan dan teknoloogi (iptek), serta perubahan gaya dan cara hidup sebagian orang tua yang telah membawa perubahan sosial yang mendasar dalam kehidupan masyarakat yang sangat berpengaruh terhadap nilai dan perilaku anak. Penyimpangan tingkah laku atau perubahan melanggar hukum yang dilakukan oleh anak, antara lain disebabkan oleh faktor di luar diri anak. Data anak yang berhadapan dengan hukum dari Dirjen Pemasyaraktan menunjukkan bahwa tingkat kriminalitas serta pengaruh negatif penyalahgunaan norkoba, psikotropika, dan zat adiktif semakin meningkat. Pembinaan adalah suatu proses penggunaan manusia, alat peralatan, uang, waktu, metode dan sistem yang didasarkan pada prinsip tertentu untuk pencapaian tujuan yang telah ditentukan dengan daya dan hasil yang sebesarbesarnya”. (Musanef,1991:11). Miftah Thoha dalam bukunya yang berjudul "Pembinaan Organisasi" mendefinisikan, pengertian pembinaan bahwa :

1. Pembinaan adalah suatu tindakan, proses, atau pernyataan menjadi lebih baik.

2. Pembinaan merupakan suatu strategi yang unik dari suatu sistem pambaharuan dan perubahan (change).

3. Pembinaan merupakan suatu pernyataan yang normatif, yakni

Jurnal Civic Hukum Volume 3, Nomor 1, Mei 2018, hal. 1-8 
menjelaskan bagaimana perubahan dan pembaharuan yang berencana serta pelaksanaannya.

4. Pembinaan berusaha untuk mencapai efektivitas, efisiensi dalam suatu perubahan dan pembaharuan yang dilakukan tanpa mengenal berhenti. (Miftah,1997:16-17).

Anak jalanan merupakan salah satu contoh semakin maraknya pergaulan bebas dikalangan remaja yang hingga saat ini semakin tahun semakin mengalami peningkatan. Luputnya pengawasan orang tua terhadap anaknya menjadikan ini salah satu faktor yang membuat mereka melakukan penyimpangan secara tingkah laku sosial. Namun anak jalanan disini tidak hanya anak yang melakukan tindakan-tindakan yang berada diluar norma, anak-anak dibawah umur yang menjadi pengemis atau pengamen seolah menjadi bagian dari kehidupan anak jalanan.

Kurangnya pengawasan orang tua serta lemahnya tindakan pemerintah membuat mereka semakin bebas dalam kehidupannya. Tak jarang anak jalanan ini menimbulkan masalah yang meresahkan masyarakat sekitar, aksi kriminalitas yang dilakukan anak jalanan dengan jelas menyadarkan kita bahwa tidak adanya peran orang tua dan tindakan tegas dari pemerintah. Anak yang seharusnya mendapat pendidikan, mendapat perhatian dari orang tua, keluarga, dan masyarakat malah lebih menyenangi kehidupan bebas diluar tanpa adanya pengawasan dari orang-orang terdekat.

Pada anak jalanan, hak dan kewajibannya kurang diperhatikan dengan baik. Maka dari itu, perlu adanya perhatian yang khusus dari pemerintah, dan masyarakat sekitar, sehingga hak dan kewajiban tersebut dapat terpenuhi dengan baik, seperti anak pada umumnya. Dinegara Indonesia itu sendiri, anak jalanan tidak begitu diperhatikan oleh pemerintah itu sendiri. Hal ini menyebabkan banyak anakanak Indonesia, dimana sebagai anak penerus bangsa mengalami degradasi moral dan etika, dikarenakan tidak adanya payung atau lembaga pemerintah untuk mengayomi anak-anak jalanan untuk mencapai apa yang mereka cita-citakan.

Di Indonesia itu sendiri, anak jalanan dari tahun ke tahun mengalami peningkatan yang begitu signifikan, terutama dikotakota besar.Jumlah anak jalanan (anjal) terus meningkat. Saat ini tercatat di Kementerian Sosial (Kemensos) mencapai sekitar 4,1 juta (2016). Menteri Sosial Khofifah Indar Parawansa menyebutkan jumlah anak jalanan meningkat 100 persendibandingkan 2015.

Di Malang data anak jalanan berdasarkan identifikasi razia per tanggal 20 Agustus 2015 mencapai 72 anak sedangkan pada tahun 2016 anak jalanan yang berhasil di identifikasi razia sebanyak 45 anak. (Data Dinsos Kota Malang th.2016)

Pemerintah Kota Malang mengeluarkan Peraturan Daerah Kota Malang Nomor 9 Tahun 2013 tentang penanganan Anak Jalanan, Pengemis, dan Gelandangan. Dengan adanya, peraturan pemerintah ini, diharapkan akan menanggulangi permasalahan mengenai anak jalanan. Akan tetapi, dengan adanya peraturan ini, belum dapat menanggulangi anak jalanan secara keseluruhan.

Di Malang sendiri sudah banyak sekali kelompok masyarakat yang mendirikan tempat naungan anak-anak jalanan, contohnya Griya Baca dan Pondok Pesantren Salafiyah Sabilul Hikmah. Pondok Pesantren Salafiyah Sabilul Hikmah beralamat di Jl.Polowijen I/190 
RT 04 RW 02, Kecamatan Belimbing, 65126 Kota Malang. Gus Ubaidillah Hamid “G” sebagai pendiri sekaligus pengasuh Pondok Pesantren Salafiyah Sabilul Hikmah . Hingga saat ini, ada 71 anak jalanan yang dibina di Ponpes ini. Di tempat tersebut, anak-anak mendapat pendidikan non-formal dan mendapat pembinaan secara khusus, ditempat tersebut mereka dibina agar dapat diterima kembali oleh keluarga dan masyarakat. Di tempat tersebut, anak-anak mendapat pendidikan non-formal dan mendapat pembinaan secara khusus, ditempat tersebut mereka dibina agar dapat diterima kembali oleh keluarga dan masyarakat.

Bercermin dari masalah diatas, maka perlu adanya bentuk nyata dari pemerintah kota Malang dalam melindungi anak jalanan beserta hak-nya. Dengan adanya bentuk kepedulian dari pemerintah, maka secara jelas pemerintah telah membuktikan kinerjanya melaksanakan tugasnya "anak jalanan, pengemis, dan gelandangan dipelihara oleh negara”.

Adanya perlindungan anak merupakan perwujudan dari keadilan dalam suatu masyarakat, dengn demikian maka perlindungan anak harus diusahakan dalam berbagai bidang kehidupan bernegara dn bermasyarakat. (Arif Gosita 1993:103)

\section{METODE}

Pada penelitian tentang "Model Pembinaan Anak Jalanan di Pondok Pesantren Salafiyah Sabilul Hikmah “ ini menggunakaan pendekatan kualitatif. Penelitian kualitatif adalah prosedur penelitian yang menghasilkan data deskriptif berupa kata-kata tertulis atau lisan dari orang-orang atau prilaku yang dapat diamati. Oleh karena itu, peneliti memilih pendekatan kualitatif untuk mempermudah peneliti dalam mendiskripsikan dan menganalisis fenomena, aktivitas sosial, gejala, sikap dan pandangan seseorang atau kelompok ataupun peristiwa yang terjadi dilapangan. Selain itu juga ada beberapa pertimbangan, yaitu pertama, metode kualitatif lebih mudah apabila berhadapan dengan pernyataan ganda.

Pembinaan adalah suatu proses penggunaan manusia, alat peralatan, uang, waktu, metode dan sistem yang didasarkan pada prinsip tertentu untuk pencapaian tujuan yang telah ditentukan dengan daya dan hasil yang sebesar-besarnya”. (Musanef,1991:11)

Menurut Moleong (2006) dalam Prastowo (2011:36) ada tiga model analisis data yang selama ini digunakan dalam penelitian kualitatif yaitu metode perbandingan tetap, metode analisis data menurut Spradley dan metode analisis data menurut Miles dan Huberman terdapat empat jalur analisis data kualitatif, yaitu mencakup : (1) pengumpulan data, (2) reduksi data, (3) penyajian data, dan (4) penarik kesimpulan.

Penelitian ini dilakukan di Pondok Pesantren Salafiyah Sabilul Hikmahberalamat di Jl.Polowijen I/190 RT 04 RW 02, Kecamatan Blimbing, 65126 Kota Malanguntuk dapat mewawancarai anak yang telah mendapat pembinaan dan salah satu pengurus yang berwenang dalam pembinaan anak-anak jalanan ini. Mendatangi dinas sosial untuk mendapat informasi dan data pihak yang berwenang menangani anak jalanan di Kota Malang.

Waktu penelitian adalah waktu dimana penelitian ini dilaksanakan mulai dari penyusunanlaporan penelitian hingga selesai penulisan laporan penelitian. Diperkirakan proses penyelesaian penelitian ini memerlukan waktu 1 bulan. Dimulai pada bulan Februari 2017 dan selesai pada bulan Maret 2017. 


\section{HASIL DAN PEMBAHASAN}

Berdasarkan hasil penelitian yang telah diuraikan diatas akan dijelaskan lebih lanjut pada pembahasan dalam beberapa subbab-subbab ini sebagai berikut: 1) Bagaimana model pembinaan yang dilakukan oleh Pondok Pesantren Salafiyah Sabilul Hikmah, 2) Apa saja kendala yang dihadapi oleh Pondok Pesantren Salafiyah Sabilul Hikmah, 3) Apa solusi yang diambil oleh pengurus Pondok Pesantren Salafiyah Sabilul Hikmah untuk menghadapi kendala tersebut. Adapun pembahasannya sebagai beikut:

\section{Model Pembinaan yang dilakukan oleh Pondok Pesantren Salafiyah Sabilul Hikmah}

Berdasarkan hasil penelitian yang telah diuraikan pada pembahasan sebelumnya, peranan Pondok Pesantren Salafiyah Sabilul Hikmah mempunyai peran penting dalam pembinaan anak jalanan. Banyak ditemui anak jalanan di Kota Malang dan di Indonesia sendiri data anak jalanan tercatat di Kementerian Sosial (Kemensos) mencapai sekitar 4,1 juta (2016).

Pengajar atau pengasuh di Pondok Pesantren Salafiyah Sabilul Hikmah sangat berperan penting dalam membina anakanak jalanan yaitu dengan melakukan pembinaan melalui pendekatan secara personal sosial dan secara agama. Pengajar dituntut untuk dapat memahami setiap anak agar pembinaan yang dilakukan tepat dan dapat diterima oleh setiap individu anak tersebut. Hal ini sesuai dengan Peraturan Daerah (Perda) Kota Malang Nomor 9 Tahun 2013 pasal 1 ayat (8) yaitu pembinaan adalah segala upaya atau kegiatan yang dilakukan oleh pemerintah dan/ atau masyarakat untuk mengatasi masalah anak jalanan, gelandangan, pengemis, dan keluarganya supaya dapat hidup dan mencari nafkah dngan tetap mengutamakan hak-hak dasar bagi kemanusiaan.

Hal ini dilakukan agar para santri dapat dibina untuk bisa mengembalikannya menjadi anak sebagaimana mestinya. Mereka dibina agar dapatmenjalani kehidupan normal seperti sediakala dan dapat diterima lagi oleh keluarga maupun masyarakat sekitar. Adapun kegiatan di Pondok Pesantren Salafiyah Sabilul Hikmah, yaitu Sholat wajib tepat waktu, belajar dan mengaji Kitab Suci Al-Qur'an, diajarkan mandiri dengan diberi modal berjualan diwarung untuk dapat memenuhi keperluan tambahan sehari-hari, kegiatan rutin mengaji Surat Yasin setiap setelah Sholat Magrib, kegiatan keputrian setiap Jumat untuk santri perempuan.

Kegiatan-kegiatan yang dilakukan bertujuan untuk dapat merubah secara pribadi agar dapat diterima kembali oleh keluarga maupun masyarakat disekitarnya. Anak-anak jalanan ini harus dibina agar dapat berubah dan merasa mendapat perlindungan. Hal ini sesuai dengan Peraturan Daerah (Perda) Kota Malang Nomor 9 Tahun 2013 pasal 1 ayat (7) perlindungan anak adalah segala kegiatan untuk menjamin dan melindungi anak agar dapat hidup, tumbuh, berkembang dan berpartisipasi secara optyimal sesuai dengan harkat dan martabat, kemanusiaan serta mendapat perlindungan dari kekerasan, diskriminasi dan eksploitasi yang mempunyai masalah dijalanan.

Berdasarkan hasil wawancara, dokumentasi, dan observasi serta didukung oleh beberapa Peraturan Daerah (Perda) dapat disimpulkan bahwa model pembinaan yang digunakan oleh Pondok Pesantren Salafiyah Sabilul Hikmah adalah pembinaan secara personal sosial dan pendekatan secara agama. Selain pembinaan, anak

Anita Dwi Agustin, Rohmad Widodo dan M. Syahri. Model Pembinaan Anak Jalanan di Pondok Pesantren Salafiyah Sabilul Hikmah Malang 
jalanan ini mendapat perlindungan sehingga mereka merasa nyaman dan merasa terlindungi, dengan ini mereka dapat berubah menjadi pribadi yang lebih baik.

Mengacu pada Alternatif model penanganan (pembinaan) anak jalanan mengarah kepada 3 jenis model yaitu family base, institutional base dan multi-system base. Pembinaan anak jalanan di Pondok Pesantren Salafiyah Sabilul Hikmah adalah jenis Institutional base yaitu, model pemberdayaan melalui pemberdayaan lembaga-lembaga sosial di masyarakat dengan menjalin networking melalui berbagai institusi baik lembaga pemerintahan maupun lembaga sosial masyarakat.

\section{Kendala yang dihadapi oleh Pondok Pesantren Salafiyah Sabilul Hikmah}

Berdasarkan hasil analisis data yang telah diuraikan diatas mengungkapkan bahwakendala yang paling menonjol yang dihadapi oleh Pondok pesantren Salafiyah Sabilul Hikmah dalam pembinaannya adalah anak-anak yang sangat susah diatur karena masa peralihan dari hidup di jalanan ke kehidupan di dalam pesantren. Kendala dari biaya operasional, tidak ada bantuan dari pemerintah untuk mencukupi biaya kehidupan anak-anak setiap harinya.

Berkaitan dengan itu, Perda Kota Malang Nomor 9 Tahun 2003 Tentang Penanganan Anak Jalanan, Gelandangan dan Pengemis Pasal 3 Penanganan anak jalanan, gelandangan dan pengemis, bertujuan:

a. mencegah dan mengantisipasi meningkatnya komunitas anak jalanan,gelandangan dan pengemis;

b. mencegah penyalahgunaan komunitas anak jalanan, gelandangan, dan pengemis dari eksploitasi pihak-pihak tertentu; c. mendidikan komunitas anak jalanan, gelandangan, dan pengemis agar dapat hidup secara layak dan normal sebagaimana kehidupan masyarakat umumnya;

d. memberdayakan para anak jalanan, gelandangan dan pengemis untukdapat hidup mandiri secara ekonomi dan sosial; dan

e. meningkatkan peran serta dan kesadaran Pemerintah Daerah, dunia usaha dan elemen masyarakat lainnya untuk berpartisipasi dalam penanganan anak jalanan, gelandangan, dan pengemis.

Perda Kota Malang Nomor 9 Tahun 2003 Tentang Penanganan Anak Jalanan, Gelandangan dan Pengemis pasal 17 tentang sumber dana yaitu:

Beban biaya untuk penangan anak jalanan, gelandangan dan pengemis, bersumber dari :

a. Anggaran Pendapatan dan Belanja Daerah;

b. Sumber lain yang sah dan tidak mengikat sesuai dengan ketentuan peraturan perundang-undangan.

Kendala yang muncul ini mengharuskan pihak Pemerintah Daerah, dunia usaha dan elemen masyarakat lainnya untuk berpartisipasi dalam penanganan anak jalanan, gelandangan, dan pengemis. Keikut sertaan semua elemen ini dibutuhkan untuk memaksimalkan pembinaan agar tidak menimbulkan berbagai kendala yang dapat menghambat berjalannya pembinaan ini.

Solusi yang diambil oleh pengurus Pondok Pesantren Salafiyah Sabilul Hikmah Untuk Menghadapi Kendala Tersebut

Berdasarkan hasil analisis data yang telah diuraikan diatas mengungkapkan 
bahwa solusi untuk mengatasi hambatan yang muncul dalam pembinaan anak jalanan di Pondok Pesantren Salafiyah Sabilul Hikmah yaitu pembinaan dilakukan dengan pendekatan secara personal sosial, Abah membuat anak-anak merasa nyaman dan merasa terlindungi sehingga anak-anak dapat berubah. Pendekatan secara agama agar mereka lebih mantap melakukan perubahan baik untuk diri mereka sendiri. Untuk kendala keuangan, Abah hanya mengandalkan uang pribadi, dari perhiasan sampai tabungan Abah gunakan untuk mencukupi sarana dan prasarana anakanak sehari-hari. Selain menggunakan uang pribadi, Abah memodali anak-anak membuka warung kecil-kecilan dimana keuntungannya untuk biaya tambahan sehari-hari mereka.Hal ini dilakukan untuk mengubah dan menjadikan anak-anak lebih baik lagi kedepannya dan mereka tidak mudah terpengaruh lagi oleh dunia bebas jalanan.

Berkaitan dengan ini, pembinaan menurut Peraturan Daerah (Perda) Kota Malang Nomor 9 Tahun 2013 pasal 1 ayat (8) yaitu adalah segala upaya atau kegiatan yang dilakukan oleh pemerintah dan/ atau masyarakat untuk mengatasi masalah anak jalanan, gelandangan, pengemis, dan keluarganya supaya dapat hidup dan mencari nafkah dngan tetap mengutamakan hak-hak dasar bagi kemanusiaan. Untuk mengatasi kendala anak-anak yang susah diatur disini Pondok Pesantren Salafiyah Sabiul Hikmah melakukan pembinaan secara personal sosial dimana anak diberikan kenyamanan dan merasa dilindungi.

Solusi yang diambil oleh “G” selaku pendiri dan pengasuh Pondok Pesantren Salafiyah Sabilul Hikmah selain menggunakan uang pribadi yaitu dengan membuatkan anak-anak usaha warung kecil-kecilan dimana selain keuntungan yang diperoleh untuk tambahan memenuhi kehidupan sehari-hari, “G” juga mengajarkan kemandirian kepada anakanak. Ini sesuai dengan alternatif pembinaan anak jalanan oleh Islamic Education yaitu Institutional base, adalah model pemberdayaan melalui pemberdayaan lembaga-lembaga sosial di masyarakat dengan menjalin networking melalui berbagai institusi baik lembaga pemerintahan maupun lembaga sosial masyarakat.

Inti dari poin ini adalah diberikannya pembinaan dan keterampilan agar anak-anak jalanan ini dapat merubah kehidupannya dan mampu hidup mandiri jauh dari kata anak jalanan seperti belumnya.

\section{SIMPULAN}

Berdasarkan hasil penelitian dan pembahasan pada bab sebelumnya, dapat disimpulkan bahwa sebagai beerikut: a) Model pembinaan yang diterapkan di Pondok Pesantren Salafiyah Sabilul Hikmah yaitu pendekatan secara personal sosial dan pendekatabn secara agama. Pembinaan ini mengacu pada Hal ini sesuai dengan Peraturan Daerah (Perda) Kota Malang Nomor 9 Tahun 2013 pasal 1 ayat (7) dan (8) serta Mengacu pada Alternatif model penanganan (pembinaan) anak jalanan mengarah kepada 3 jenis model yaitu family base, institutional base dan multi-system base. Pembinaan anak jalanan di Pondok Pesantren Salafiyah Sabilul Hikmah adalah jenis Institutional base yaitu, model pemberdayaan melalui pemberdayaan lembaga-lembaga sosial di masyarakat dengan menjalin networking melalui berbagai institusi baik lembaga pemerintahan maupun lembaga sosial masyarakat. b) Kendala yang paling menonjol yang dihadapi oleh Pondok 
pesantren Salafiyah Sabilul Hikmah dalam pembinaanya adalah anak-anak yang sangat susah diatur karena masa peralihan dari hidup di jalanan ke kehidupan di dalam pesantren. Kendala dari biaya operasional, tidak ada bantuan dari pemerintah untuk mencukupi biaya kehidupan anak- anak setiap harinya. c) Solusi dalam mengatasi kendala di Pondok Pesantren Salafiyah Sabilul Hikmah yaitu peembinaan dilakukan dengan pendekatan secara personal sosial, Gus Ubaidillah Hamid membuat anak-anak merasa nyaman dan merasa terlindungi sehingga anak-anak dapat berubah. Pendekatan secara agama agar mereka lebih mantap melakukan perubahan baik untuk diri mereka sendiri. Untuk kendala keuangan, Gus Ubaidillah Hamid hanya mengandalkan uang pribadi, dari perhiasan sampai tabungan Gus Ubaidillah Hamid gunakan untuk mencukupi sarana dan prasarana anak-anak sehari-hari. Selain menggunakan uang pribadi, Gus Ubaidillah Hamids memodali anak-anak membuka warung kecil-kecilan dimana keuntungannya untuk biaya tambahan sehari-hari mereka.

\section{DAFTAR PUSTAKA}

Gosita, Arif. (1993). Masalah Korban Kejahatan. Jakarta: Akademika Presindo.

Moleong, Lexy, J. (2006). Metodologi Penelitian Kualitatif. Bandung: Remaja Rosdakarya.

Musanef. (1991). Manajemen Kepegawaian Di Indonesia. Jakarta: CV Haji Masagung.
Nugroho, F. A. Realitas Anak Jalanan di Kota Layak Anak ( Studi Kasus Anak Jalanan di Kota Surakarta). Other Skripsi Universitas Sebelas Maret (Online) http://www. jurnal.fkip.uns.ac.id/index.php/ sosant/article/viewFile/3391/2377 diakses desember 2016

Prastowo, Andi. 2011.Memahami Metode-Metode Penelitian. Jogjakarta: Ar-RuzzMedia.

Thoha, Miftah. (1997). Pembinaan Organisasi Proses Diagnosa dan Interval. Jakarta : PT. Raja Grafindo Persada

Departemen Sosial dan UNDP di Jakarta dan Surabaya (BKSN, 2002:2-4) 